AJHSE Vol: 2 (2): 103-114, 2021

DOI: 10.52417/ajhse.v2i2.173

Accepted Date: Nov. 30, 2021

(C) 2021. CC License 4.0

www.ajhse.org

\title{
ASSOCIATION OF DIETARY AND LIFESTYLE FACTORS ON BLOOD PRESSURE CONTROL AMONG ADULT HYPERTENSIVE PATIENTS ATTENDING A UGANDAN TERTIARY HOSPITAL
}

\section{${ }^{1}$ Nakalega, A. P., ${ }^{2}$ Mugenyi, L., ${ }^{3}$ Nuwabaine, L., ${ }^{*}$ Amperiize, M., \& ${ }^{5}$ Tabusibwa, K. B.}

\author{
${ }^{1}$ Department of Public health and Nutrition, Victoria University, Kampala, Uganda \\ ${ }^{2}$ Department of Community Health and Behavioral Sciences, School of Public health, Makerere University, Kampala, Uganda \\ ${ }^{3}$ Department of Nursing and Midwifery, Makerere University, Kampala, Uganda \\ ${ }^{4}$ Department of Disease Control and Environmental Health, School of Public Health, Makerere University, Kampala, Uganda \\ ${ }^{5}$ Department of Epidemiology and Biostatistics, School of Public health, Makerere University, Kampala, Uganda \\ *Corresponding Author Email: mathius166@gmail.com Phone: +256 774861595/700103841
}

\begin{abstract}
$\mathrm{H}$

ypertension is an important worldwide public-health challenge due to its high prevalence and being a risk factor for cerebrovascular, cardiovascular, and chronic renal diseases. Despite these risk factors,

blood pressure control among hypertensive patients is still poor. The main objective was to assess dietary and lifestyle factors associated with uncontrolled blood pressure control among Ugandan hypertensive patients at Kiruddu hospital. Materials and methods: A cross-sectional study involving 271 adult hypertensive patients attending the outpatient hypertensive clinic was enrolled. Data were obtained on dietary, lifestyle factors (alcohol intake, smoking status, and level of physical activity), social demographics, Body Mass Index (BMI), comorbidities, and adherence to hypertensive medication. An average of the current and previous two Blood pressure readings was recorded. Factors associated with uncontrolled blood pressure were assessed using a multivariate logistic regression model. Results: The mean age of study participants was $57 \pm 0.76$ years, with female dominance (77.9\%). Among the study participants, 121 (44.7\%) had uncontrolled BP. Dietary factors that were associated with uncontrolled blood pressure with adjusted OR (95\%CI) included consumption of raw salt: 4.18 (1.32-13.24) and inadequate fruit consumption: 2.18 (1.26-3.75) while clinical factors included being overweight: 2.51 (1.27-4.95) and poor adherence to antihypertensive medications prescribed: 1.82 (1.03-3.21). Conclusion: The proportion of hypertensive patients with uncontrolled Blood Pressure was high (44.7\%). Consumption of raw salt, inadequate fruit consumption, being overweight and poor adherence to antihypertensive medication were significantly associated with uncontrolled BP. From these findings, factors that were associated with the control of blood pressure are modifiable.
\end{abstract}

Keywords: Blood pressure, Hypertension, Risk factors, Dietary, Lifestyle, Clinical factors

LICENSE: This article by African Journal of Health, Safety and Environment (AJHSE) is licensed and published under the Creative Commons Attribution License 4.0 International License, which permits unrestricted use, distribution, and reproduction in any medium, provided this article is duly cited.

COPYRIGHT: The Author(s) completely retain the copyright of this published article.

OPEN ACCESS: The Author(s) approves that this article remains permanently online in the open access (OA) model 


\section{INTRODUCTION}

Hypertension is an important worldwide public-health challenge due to its high prevalence and a major risk factor for stroke, ischemic heart disease, congestive heart failure, myocardial infarction, and renal failure among others (WHO 2010). According to WHO, 1.39 billion people are living with hypertension representing $31 \%$ of the global adult population and of this, approximately 80 million cases occur in Sub-Saharan Africa representing $46 \%$ of the world's hypertensive population and this is estimated to increase to 150 million in 2025 (WHO, 2013). In Uganda, the findings from the National Non-Communicable Diseases Risk Factor Survey have shown an overall prevalence of hypertension of 26.4\% (Guwatudde et al., 2015). Control of hypertension remains minimal in the world despite the existence of clinical guidelines recommended from several trials which dictate; following medication, dietary and exercise regimens, smoking cessation, and minimizing alcohol consumption (Appel et al., 2010, McEvoy et al., 2013). Uncontrolled BP accounts for 9.4 million deaths and is responsible for morbidity associated with approximately $54 \%$ of strokes, $47 \%$ of ischemic heart disease, $25 \%$ of other cardiovascular diseases and $7 \%$ of global disability-adjusted life years, and nearly 10 million deaths per year (Lim et al., 2012).

Four behavioral risk factors play an important role in the development of hypertension. These include tobacco use, unhealthy diet, physical inactivity, and harmful use of alcohol. Other risk factors of hypertension in adults include poor stress management, obesity, and having diabetes mellitus (WHO 2013). The main objective in the management of hypertension is to attain an optimal BP to avert morbidities and mortalities associated with raised BP. Inadequate BP control in more than two-thirds of people living with hypertension has been attributed mainly to poor compliance to therapy including dietary and lifestyle modification. There are limited data on the prevalence of BP control yet populations could benefit from control efforts (Kayima et al., 2013).

The effects of hypertension if not controlled are diverse and can consequently lead to death. Given that populations in low- and middle-income countries are especially being affected through engagement in easily modifiable risk factors like unhealthy diet, tobacco use, harmful use of alcohol, and physical inactivity, adults need to be able to control their BP by modifying their lifestyle and diet as these approaches may reduce on the cost of care at health facilities and improve their quality of life. This study therefore aimed at quantifying the proportion of patients who had uncontrolled blood pressure and to identify dietary, lifestyle, and clinical factors associated with BP control among hypertensive patients under care at Kiruddu hospital.

\section{MATERIALS AND METHODS}

\section{STUDY DESIGN}

The study employed a descriptive cross-sectional design.

\section{STUDY SITE}

The study was conducted at the outpatient hypertensive clinic of Kiruddu general referral hospital, an extension of Mulago National Referral Hospital located in Kampala, the capital city of Uganda. The site was chosen because it receives a high number of patients diagnosed with hypertension from different dispensaries, health centers, and hospitals all over the country. This outpatient clinic sees approximately 100 individuals with hypertension per week. 


\section{RECRUITMENT OF STUDY PARTICIPANTS AND SAMPLING TECHNIQUE}

Participants were eligible if they were 18 years or older with a known diagnosis of hypertension presenting at Kiruddu hypertensive outpatient clinic at least for the second time at the time of the study (February 2019). Participants were excluded if their data of previous BP readings were not available. Participants who met the eligibility criteria represented the target study population. Consecutive sampling was used as participants were recruited as they came for each clinic day until the required sample size was achieved.

\section{SAMPLE SIZE DETERMINATION}

The sample size was calculated using the Kish Leslie (1969) formula for a single proportion. Taking a prevalence of $20 \%$ (Kayima et al., 2015). A z-score of 1.96 (95\% CI), an error rate of 5\% were used yielding a minimum sample of 271 respondents.

\section{STUDY VARIABLES}

Trained Research Assistants collected data on dietary and lifestyle factors, social demographics, and clinical factors. Socio-demographic information included age, gender, marital status, educational attainment, and occupation. Dietary patterns of the study participants were assessed based on the recommended DASH diet using a food frequency questionnaire of the foods consumed in the last one month including salt; grains; fruits; vegetables; nut/seeds, and legumes; dairy; meat; fat; and sweets (DASH, 2004). Clinical factors assessed included Body mass index, comorbidities, and adherence to hypertensive medication. Adherence was assessed using the Morisky adherence scale (MMAS-8). It is an eight-question scale with $\mathrm{Yes}=0$ or $\mathrm{No}=1$ answers where a score of $\geq 6$ is termed as good adherence while a score of $<6$ is termed as poor adherence (Morisky et al., 1986).

Study participants were also interviewed on their lifestyle behaviors such as alcohol use, cigarette smoking, and level of physical activity. Alcohol consumption was defined as 'drinker' and 'non-drinker. Cigarette smoking status was defined as never, former, or current smoker. Smoking was classified as taking any form and number of cigarettes. Physical activity was assessed by asking participants if they are involved in either vigorous exercise, moderate exercise, or no exercise. Participants who spent at least 30 minutes/day of moderate-intensity activities 5 days a week and those who spent at least 10 minutes/ day of vigorous physical activities 5 days a week fulfilled WHO minimum recommendations for physical activity (WHO, 2010a). To ascertain blood pressure control, the average of the current and previous BP readings (measured in the last four months from the patient file) was used as the overall BP reading. Body mass index (BMI) was divided into four categories underweight $<18.5 \mathrm{~kg} / \mathrm{m}^{2}$, Normal weight $18.5-24.99 \mathrm{~kg} / \mathrm{m}^{2}$, Overweight $25-29.99 \mathrm{~kg} / \mathrm{m}^{2}$ and Obese $\geq 30 \mathrm{~kg} / \mathrm{m}^{2}($ WHO, $2010 b)$.

\section{DATA MANAGEMENT AND STATISTICAL ANALYSIS}

Double data entry into the computer was done using Epi data version 3.1 statistical package and transported to STATA 13.0 for analysis. Descriptive statistics were used to analyze demographic characteristics. At bivariate analysis, chi-square and fishers' exact tests were used to test categorical variables that were independently associated with blood pressure control status. Significant variables at bivariate analysis $(\mathrm{P}<0.2)$ were taken to multivariate analysis using logistic regression to reveal potential associations with uncontrolled BP. Adjustment (via modeling) was done to control for confounding and identify effect modification. A p-value of less than 0.05 was 
used to determine statistical significance. The odds ratio was used as a measure of association. The HosmerLemeshow Goodness-of-Fit test indicated a good model fit $(\mathrm{p}=0.346)$.

\section{ETHICAL PERMISSION}

Ethical clearance was sought from higher Degrees Research and Ethics Committees of Makerere University before the implementation of the research study in 2019. Clearance Number (FWA 00011353). Then permission was sought from Mulago hospital IRB and Kiruddu hospital. Written informed consent was obtained from all study participants before enrollment into the study.

\section{RESULTS}

\section{BACKGROUND CHARACTERISTICS OF STUDY PARTICIPANTS AND THEIR RELATIONSHIP WITH UNCONTROLLED VERSUS CONTROLLED BP}

Overall, 271 respondents participated in the study. Their mean age was $57 \pm 0.76$ years which ranged from $22-86$ years. Most of the respondents were females 211 (77.9\%), 145 (53.5\%) were currently married and $103(38.0 \%)$ identified themselves as Catholics. As shown in Table 1, about 43\% (117) were unemployed, 127 (46.9\%) attained at least secondary level education, and close to three-quarters (75.7\%) were urban dwellers. Eighty-three (30.6\%) of the respondents had been diagnosed with hypertension for more than 10 years while only $48(17.7 \%)$ had the disease for less than two years.

The overall proportion of uncontrolled BP was $44.7 \%$ (95\% CI: 38.7, 50.6\%). There was no statistically significant difference between uncontrolled and controlled BP in terms of sex, age, marital status, religion, rural residence, level of education, employment status, and duration with hypertension as shown in Table 1. 
Table 1. Social demographic characteristics of participants with uncontrolled BP versus controlled BP

\begin{tabular}{|c|c|c|c|c|c|c|}
\hline \multirow{2}{*}{$\begin{array}{l}\text { Background } \\
\text { factors }\end{array}$} & \multirow[t]{2}{*}{ Distribution } & \multirow{2}{*}{$\begin{array}{l}\text { Frequency }(\%) \\
\mathrm{n}=271\end{array}$} & \multicolumn{2}{|c|}{ Blood pressure control } & \multirow[t]{2}{*}{ Odds ratio $(\mathrm{CI})$} & \multirow[t]{2}{*}{ p-value } \\
\hline & & & $\begin{array}{l}\text { Uncontrolled } \\
\mathbf{n}(\%)\end{array}$ & $\begin{array}{l}\text { Controlled } \\
\mathbf{n}(\%)\end{array}$ & & \\
\hline Sex & $\begin{array}{l}\text { Male } \\
\text { Female }\end{array}$ & $\begin{array}{l}60(22.1) \\
211(77.9)\end{array}$ & $\begin{array}{l}35(23.3) \\
115(76.7)\end{array}$ & $\begin{array}{l}25(20.7) \\
96(79.3)\end{array}$ & $0.86(0.48-1.52)$ & 0.598 \\
\hline Age & $\begin{array}{l}\leq 34 \text { years } \\
35-44 \text { years } \\
45-54 \text { years } \\
55-64 \text { years } \\
65 \text { and above }\end{array}$ & $\begin{array}{l}10(3.7) \\
38(14.0) \\
55(20.3) \\
100(36.9) \\
68(25.1)\end{array}$ & $\begin{array}{l}5(3.3) \\
18(12.0) \\
30(20.0) \\
55(36.7) \\
42(28.0)\end{array}$ & $\begin{array}{l}5(4.1) \\
20(16.5) \\
25(20.7) \\
45(37.2) \\
26(21.5)\end{array}$ & $\begin{array}{l}0.90(0.22-3.62) \\
1.20(0.31-4.62) \\
1.22(0.33-4.49) \\
1.62(0.43-6.12)\end{array}$ & $\begin{array}{l}0.882 \\
0.791 \\
0.762 \\
0.481\end{array}$ \\
\hline Marital Status & $\begin{array}{l}\text { Single } \\
\text { Married } \\
\text { Divorced/Separated } \\
\text { Widowed }\end{array}$ & $\begin{array}{l}11(4.1) \\
145(53.5) \\
70(25.8) \\
45(16.6)\end{array}$ & $\begin{array}{l}6(4.0) \\
81(54.0) \\
40(26.7) \\
23(15.3)\end{array}$ & $\begin{array}{l}5(4.1) \\
64(52.9) \\
30(24.8) \\
22(18.2)\end{array}$ & $\begin{array}{l}1.05(0.31-3.61) \\
1.11(0.31-3.99) \\
0.87(0.23-3.27)\end{array}$ & $\begin{array}{l}0.932 \\
0.872 \\
0.838\end{array}$ \\
\hline Residence & $\begin{array}{r}\text { Urban } \\
\text { Rural }\end{array}$ & $\begin{array}{l}205(75.6) \\
66(24.4)\end{array}$ & $\begin{array}{l}118(78.7) \\
32(21.3)\end{array}$ & $\begin{array}{l}87(71.9) \\
34(28.1)\end{array}$ & $0.69(0.40-1.21)$ & $0.198 *$ \\
\hline Religion & $\begin{array}{l}\text { Catholic } \\
\text { Anglican } \\
\text { Muslims } \\
\text { Pentecostal } \\
\text { Others }\end{array}$ & $\begin{array}{l}103(38.0) \\
83(30.6) \\
52(19.2) \\
24(8.9) \\
9(3.3\end{array}$ & $\begin{array}{l}53(35.3) \\
42(28.0) \\
29(19.3) \\
18(12.0) \\
8(5.33)\end{array}$ & $\begin{array}{l}50(41.3) \\
41(33.9) \\
23(19.0) \\
6(5.0) \\
1(0.8)\end{array}$ & $\begin{array}{l}0.13(0.02-1.10) \\
0.13(0.02-1.07) \\
0.16(0.02-1.35) \\
0.38(0.04-3.65)\end{array}$ & $0.054 *$ \\
\hline $\begin{array}{l}\text { Employment } \\
\text { state }\end{array}$ & $\begin{array}{l}\text { Employment } \\
\text { Unemployed }\end{array}$ & $\begin{array}{l}154(56.8) \\
117(43.2)\end{array}$ & $\begin{array}{l}82(54.67) \\
68(45.33)\end{array}$ & $\begin{array}{l}72(59.50) \\
49(40.50)\end{array}$ & $1.22(0.75-1.98)$ & 0.424 \\
\hline $\begin{array}{l}\text { Level of } \\
\text { Education }\end{array}$ & $\begin{array}{l}\text { No formal } \\
\text { Primary level } \\
\text { Secondary level } \\
\text { Tertiary }\end{array}$ & $\begin{array}{l}75(27.7) \\
69(25.5) \\
54(19.9) \\
73(26.9)\end{array}$ & $\begin{array}{l}50(33.3) \\
34(22.7) \\
31(20.7) \\
35(23.3)\end{array}$ & $\begin{array}{l}25(20.7) \\
35(28.9) \\
23(19.0) \\
38(31.4)\end{array}$ & $\begin{array}{l}0.49(0.25-0.95) \\
0.67(0.33-1.39) \\
0.46(0.24-0.89)\end{array}$ & $0.085^{*}$ \\
\hline $\begin{array}{l}\text { Duration with } \\
\text { hypertension }\end{array}$ & $\begin{array}{l}<2 \text { years } \\
2-<5 \text { years } \\
5-10 \text { years } \\
\text { More than 10years }\end{array}$ & $\begin{array}{l}48(17.7) \\
68(25.1) \\
72(26.6) \\
83(30.6)\end{array}$ & $\begin{array}{l}26(17.4) \\
38(25.5) \\
40(26.9) \\
45(30.2)\end{array}$ & $\begin{array}{l}22(18.2) \\
30(24.0) \\
32(26.4) \\
38(31.4)\end{array}$ & $\begin{array}{l}1.11(0.53-2.34) \\
1.06(0.51-2.20) \\
1.00(0.49-2.04)\end{array}$ & 0.989 \\
\hline
\end{tabular}

*Significant variables at bivariate $(\mathrm{P}<0.2)$ 


\section{DIETARY AND LIFESTYLE HABITS OF RESPONDENTS AND THEIR RELATIONSHIP WITH UNCONTROLLED VERSUS CONTROLLED BP}

Table 2 shows the dietary habits of respondents. Out of 271 participants, 243 (89.7\%) did not add raw salt to their cooked food, 117 (43.2\%) and 118 (43.5\%) were eating fruits and vegetables on most days of the week respectively. One hundred and thirteen (41.9\%) of the respondents did not take dairy products at all, only $15(5.5 \%)$ and 14 (5.2\%) had not consumed nuts and grains respectively.

One hundred and one (37.3\%) of the respondents consumed fish at least once every week and only 4 (1.5\%) consumed it every day. Fifty-three (19.6\%) reported not eating meat while about half of the respondents ate meat at least once every week (51.0\%). One hundred and fifty-three (56.0\%) take sugar every day and 96 (35.4\%) use vegetable oil while 101 (37.8\%) use animal oil every day. Only two participants $(0.7 \%)$ were current smokers, and $45(16.6 \%)$ reported that they drink alcohol daily. Over half of the patients $(56.1 \%)$ were classified as having moderate levels of physical activity.

Those who consumed raw salt were about 5.57 times more likely to have uncontrolled hypertension than those who did not $(\mathrm{p}=0.002)$. Similarly, inadequate consumption of fruits and vegetables had twice the odds of uncontrolled BP compared to adequate consumption ( $\mathrm{p}=0.000$ and $\mathrm{p}=0.005)$ respectively. Also, participants who consumed fish less than two servings a week were more likely to have uncontrolled $\mathrm{BP}(\mathrm{p}=0.014)$ and those who consumed red meat in a week were more likely to have uncontrolled BP as compared to those who did not.

Among the lifestyle habits of participants, smoking $(\mathrm{p}=0.044)$ and inadequate physical activity were associated with uncontrolled BP while alcohol consumption had no association with BP control status. Inadequate physical activity had 1.7 odds of uncontrolled BP compared to adequate physical activity and the difference between these groups was statistically significant $(\mathrm{p}=0.030)$. See Table 2 . 
Table 2: Dietary and lifestyle habits of participants with uncontrolled BP versus controlled BP

\begin{tabular}{|c|c|c|c|c|c|c|}
\hline \multirow[t]{2}{*}{ Diet and lifestyle } & \multirow[t]{2}{*}{ Distribution } & \multirow[t]{2}{*}{ n $(\%)$} & \multicolumn{2}{|c|}{ Blood pressure control } & \multirow[t]{2}{*}{ Odds ratio $(\mathrm{CI})$} & \multirow[t]{2}{*}{ p-value } \\
\hline & & & $\begin{array}{l}\text { Uncontrolled n } \\
(\%)\end{array}$ & $\begin{array}{l}\text { Controlledn } \\
(\%)\end{array}$ & & \\
\hline \multirow[t]{2}{*}{ Raw salt } & No intake & $243(89.7)$ & $126(84.0)$ & $117(96.7)$ & & \\
\hline & Raw salt intake & $28(10.3)$ & $24(16.0)$ & $4(3.3)$ & $(1.88-16.54) 5.57$ & $0.002 *$ \\
\hline \multirow[t]{2}{*}{ Fruits } & Everyday & $122(45.0)$ & $53(35.3)$ & $69(57.0)$ & & \\
\hline & $<7$ days/week & $149(55.0)$ & $97(64.7)$ & $52(43.0)$ & $2.43(1.49-3.97)$ & 0.0001 \\
\hline \multirow[t]{2}{*}{ Vegetables } & Every day & $120(44.3)$ & $55(36.7)$ & $65(53.7)$ & & \\
\hline & $<7$ days/week & $151(55.7)$ & $95(63.3)$ & $56(46.3)$ & $2.00(1.23-3.27)$ & $0.005^{*}$ \\
\hline \multirow[t]{2}{*}{ Dairy product } & $\leq 1$ cup of milk/day & $232(85.6)$ & $126(84.0)$ & $106(87.6)$ & & \\
\hline & $>1$ cup of milk/day & $39(14.4)$ & $24(16.0)$ & $15(12.4)$ & $1.35(0.67-2.7)$ & 0.402 \\
\hline \multirow[t]{2}{*}{ Nuts/ Seeds } & $4-5$ serving/week & $252(93.0)$ & $139(92.7)$ & $113(93.4)$ & & \\
\hline & $<4$ serving/week & $19(7.0)$ & $11(7.3)$ & $8(6.6)$ & $1.12(0.43-2.87)$ & 0.817 \\
\hline \multirow[t]{2}{*}{ Grains } & $4-5$ servings/day & $256(94.5)$ & $140(93.3)$ & $116(95.9)$ & $1.66(0.55-4.99)$ & 0.369 \\
\hline & $<4$ serving/day & $15(5.6)$ & $10(6.7)$ & $5(4.1)$ & & \\
\hline \multirow[t]{2}{*}{ Fish/poultry } & $\geq 2$ serving/week & $110(40.6)$ & $51(34.0)$ & $59(48.8)$ & & \\
\hline & $<2$ serving/week & $161(59.4)$ & $99(66.0)$ & $62(51.2)$ & $1.85(1.13-3.02)$ & $0.014 *$ \\
\hline \multirow[t]{2}{*}{ Red meat } & Donot take red meat & $88(32.5)$ & $43(28.7)$ & $45(37.2)$ & & \\
\hline & Consume red meat & $183(67.5)$ & $107(71.3)$ & $76(62.8)$ & $1.47(0.88-2.46)$ & $0.137 *$ \\
\hline \multirow[t]{2}{*}{ Vegetable oil } & Daily serving & $102(37.6)$ & $53(35.3)$ & $49(40.5)$ & & \\
\hline & Once in a while & $169(62.4)$ & $97(64.7)$ & $72(59.5)$ & $0.80(0.49-1.32)$ & 0.383 \\
\hline \multirow[t]{2}{*}{ Animal oil } & Do not use & $168(62.0)$ & $88(58.7)$ & $80(66.1)$ & & \\
\hline & Use animal oil & $103(38.0)$ & $62(41.3)$ & $41(33.9)$ & $0.73(0.44-1.20)$ & 0.210 \\
\hline \multirow[t]{2}{*}{ Smoking } & Never smoked & $255(94.1)$ & $137(91.3)$ & $118(97.5)$ & & \\
\hline & Ever smoked & $16(5.9)$ & $13(8.7)$ & $3(2.5)$ & $3.73(1.04-13.41)$ & $0.044 *$ \\
\hline \multirow[t]{2}{*}{ Alcohol intake } & Non- alcohol use & $222(81.9)$ & $122(81.3)$ & $100(82.6)$ & & \\
\hline & Alcohol use & $49(18.1)$ & $28(18.7)$ & $21(17.4)$ & $1.09(0.59-2.04)$ & 0.780 \\
\hline \multirow[t]{2}{*}{ Physical activity } & $\begin{array}{l}\text { Adquate physical } \\
\text { activity }\end{array}$ & $119(43.9)$ & $57(38.0)$ & $62(51.2)$ & & \\
\hline & No physical activity & $152(56.1)$ & $93(62.0)$ & $59(48.8)$ & $1.71(1.06-2.88)$ & $0.030 *$ \\
\hline
\end{tabular}

*Significant variables at bivariate $(\mathrm{P}<0.2)$

\section{CLINICAL CHARACTERISTICS OF STUDY PARTICIPANTS AND THEIR RELATIONSHIP WITH UNCONTROLLED VERSUS CONTROLLED BP}

Eight (3.0\%) of the respondents were underweight, 89 (32.8\%) were of normal weight while the rest (64.2\%) were either overweight or obese. Over half (62.4\%) of the patients were classified as having good adherence to prescribed hypertensive medications. Of all the respondents, 82 (30.3\%), 98 (36.2\%), 35 (12.9\%) had heart problems, diabetes mellitus, and other diseases (like kidney diseases) respectively which may be related to a high percentage of participants having hypertension for more than 10 years. Ninety-one $(33.6 \%)$ of the respondents did not have any known comorbidity. Overweight had twice the odds of uncontrolled BP compared to normal weight and the difference between these groups was statistically significant $(\mathrm{p}=0.007)$. 
Study participants with good adherence were 2.61 more likely to have controlled BP levels $(74.4 \%$ of patients with controlled blood pressure had good adherence levels $(\mathrm{p}<0.000)$.

Table 3: Clinical characteristics by blood pressure control status

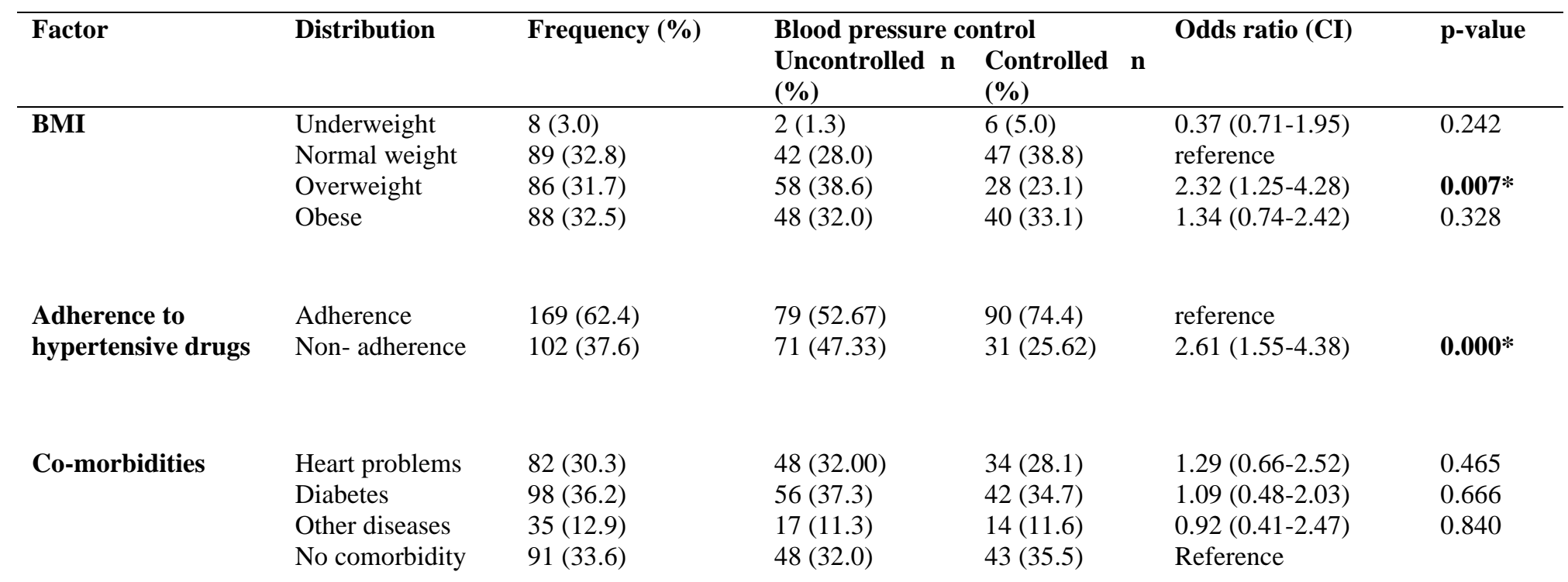

\section{Statistically significant variables at $\mathrm{p}<0.2$}

\section{FACTORS ASSOCIATED WITH BLOOD PRESSURE CONTROL AMONG HYPERTENSIVE PATIENTS}

Table 4 presents the adjusted estimates of the demographic, dietary, lifestyle, and clinical characteristics of the respondents with their unadjusted estimates. Among the dietary factors, participants who consumed raw salt were 4.18 times more likely to have uncontrolled BP (adjusted odds ratio $(\mathrm{AOR})=4.18,95 \%$ CI: $1.32-13.24, \mathrm{p}=0.015)$ as compared to those who did not. Similarly, participants who failed to consume fruits every day were 2.18 more likely to have uncontrolled BP compared to those who consumed fruits every day (AOR=2.18, 95\% CI: 1.26-3.75, $\mathrm{p}=0.005$ ). Among the clinical factors, participants who were overweight were 2.51 times more likely to have uncontrolled BP compared to their counterparts who were either underweight or had a normal body weight (AOR=2.52, 95\% CI: 1.27-4.95, $\mathrm{p}=0.008$ ). Similarly, participants who did not adhere to their antihypertensive medication were 1.82 times more likely to have uncontrolled BP compared to those who adhered to their medication $(\mathrm{AOR}=1.82,95 \% \mathrm{CI}: 1.03-3.21, \mathrm{p}=0.039)$. 
Table 4: Factors associated with blood pressure control among hypertensive patients

\begin{tabular}{|c|c|c|c|c|}
\hline Factors & Distribution & Un adjusted OR (95\%CI) & Adjusted OR (95\% CI) & p-value \\
\hline Residence & $\begin{array}{l}\text { Urban } \\
\text { Rural }\end{array}$ & $0.69(0.40-1.21)$ & & \\
\hline Religion & $\begin{array}{l}\text { Catholic } \\
\text { Anglican } \\
\text { Muslim } \\
\text { Pentecostal } \\
\text { Others }\end{array}$ & $\begin{array}{l}0.13(0.02-1.10) \\
0.13(0.02-1.07) \\
0.16(0.02-1.35) \\
0.38(0.04-3.65) \\
\text { Reference }\end{array}$ & $\begin{array}{l}0.13(0.01-1.13) \\
0.13(0.01-1.20) \\
0.12(0.01-1.15) \\
0.33(0.03-0.48)\end{array}$ & $\begin{array}{l}0.064 \\
0.072 \\
0.067 \\
0.354\end{array}$ \\
\hline Raw salt & $\begin{array}{l}\text { No intake } \\
\text { Intake of raw salt }\end{array}$ & $\begin{array}{l}\text { reference } \\
5.57(1.88-16.54)\end{array}$ & $4.18(1.32-13.24)$ & $0.015^{*}$ \\
\hline Fruit intake & $\begin{array}{l}\text { Everyday } \\
<7 \text { days/week }\end{array}$ & $\begin{array}{l}\text { reference } \\
2.43(1.49-3.97)\end{array}$ & $2.18(1.26-3.75)$ & $0.005 *$ \\
\hline Smoking & $\begin{array}{l}\text { Never smoked } \\
\text { Ever smoked }\end{array}$ & $\begin{array}{l}\text { reference } \\
3.73(1.04-13.41)\end{array}$ & $3.73(0.95-14.67)$ & 0.059 \\
\hline BMI & $\begin{array}{l}\text { Underweight } \\
\text { Normal weight } \\
\text { Overweight } \\
\text { Obese }\end{array}$ & $\begin{array}{l}0.37(0.07-1.95) \\
\text { reference } \\
2.32(1.25-4.28) \\
1.34(0.74-2.42)\end{array}$ & $\begin{array}{l}0.47(0.07-3.05) \\
2.51(1.27-4.95) \\
1.54(0.80-2.95)\end{array}$ & $\begin{array}{l}0.431 \\
\\
\text { 0.008* } \\
0.192\end{array}$ \\
\hline $\begin{array}{l}\text { Adherence to } \\
\text { drugs }\end{array}$ & $\begin{array}{l}\text { Adherence } \\
\text { Non-adherence }\end{array}$ & $\begin{array}{l}\text { Reference } \\
2.61(1.55-4.38)\end{array}$ & $1.82(1.03-3.21)$ & $0.039 *$ \\
\hline
\end{tabular}

Statistically significant variables at $\mathrm{p}<0.05$

\section{DISCUSSION}

The results showed that almost half of the participants had uncontrolled BP (44.7\%). The dietary and lifestyle factors associated with this problem were consumption of raw salt, and inadequate fruit intake while clinical factors including being overweight and non-adherence to prescribed antihypertensive medication.

Controlling BP in people with hypertension to reduce cardiovascular morbidity and mortality is a major challenge and a public health problem in many developing countries including Uganda. This study revealed that $44.7 \%$ of hypertensive patients had uncontrolled BP despite being on follow-up at Kiruddu hospital.

This finding coincides with studies in Ethiopia (42.9\%) where high levels of uncontrolled BP were reported (Teshome et al., 2018). However, studies in Ghana (57.7\%) and Kenya (66.4\%) had a much higher uncontrolled BP percentage (Mutua et al., 2014: Sarfo et al., 2018). This might be due to the difference in the study population (community vs hospital-based study, elderly vs general population) and single BP measurements. 
Some previous studies have identified a relationship between socio-demographic factors and having uncontrolled BP ( Babiker et al., 2013: Brown and Bussell, 2010: Kayima et al., 2013: Musinguzi and Nuwaha,2013). Studies have reported an association between increasing age and uncontrolled BP (Mejía-Rodríguez et al., 2009), while a study by Teshome et al., showed that hypertensive patients older than 60 years were three times more likely to control their BP as compared to the age group of 18-40 years (Teshome et al., 2018). These results could be due to different age categorizations, and the high percentages of females (77.9\%). Similar to our study, age was not associated with uncontrolled BP in a study by Basu and Millett (Basu and Millett, 2013). Rural residence and level of education were not associated with BP control in this study. However, in the Prospective Urban Rural Epidemiology (PURE) study, better BP control was seen among urban than rural dwellers (Chow et al., 2013) while in a Ghanaian study, higher rates of uncontrolled BP were seen among urban than rural residents (Sarfo et al., 2018).

Dietary factors associated with uncontrolled BP in this study included: inadequate fruit consumption and raw salt consumption. These results are similar to those from a previous study in Ethiopia where the use of top added salt on a plate and failure to consume fruits and vegetables on most days of the week were negatively associated with optimal BP control (Teshome et al., 2018). This may be because high salt intake causes fluid retention which increases cardiac burden resulting in high BP.

Overweight and obesity were common among our study subjects (31.7\% and $32.5 \%$ respectively). This study showed that BP control is poor in overweight patients. This finding is coherent with similar studies in Angola and Uganda (Musinguzi et al., 2015, Pires et al., 2013) but BMI had no association with BP control in a Nigerian study (Adebayo et al., 2014).

Poor adherence to prescribed anti-hypertensive medication captured by the Morisky Medication Adherence Scale was a key determinant of BP control as expected. This finding is in line with that of previous studies in Ghana and Ethiopia (Sarfo et al., 2018, Teshome et al., 2018). Reasons why other clinical variables did not show any association with BP control contrary to other studies may be attributed to the use of patient files or self-reported methods to ascertain if a patient had any other diseases.

\section{CONCLUSIONS}

The proportion of hypertensive patients with uncontrolled BP among this study population was high (44.7\%). Dietary factors including consumption of Raw salt, inadequate fruit consumption and clinical factors including overweight and poor adherence to antihypertensive medication were the factors significantly associated with uncontrolled BP. As identified in this study, many of the factors that were associated with blood pressure control are fortunately modifiable.

\section{ACKNOWLEDGMENTS}

I extend sincere gratitude to DAAD (Deutscer Akademischer Austausch Dienst (Germany Academic Exchange Service) for the academic scholarship.

\section{CONFLICT OF INTERESTS}

The authors have no competing interests 


\section{REFERENCES}

Adebayo, R. A., Balogun, M. O., Adedoyin, R. A., Obashoro-John, O. A., Bisiriyu, L. A. \& Abiodun, O. O. 2014. Prevalence and pattern of overweight and obesity in three rural communities in southwest Nigeria. Diabetes, metabolic syndrome, and obesity: targets and therapy, 7,153.

Appel, L. J., Wright JR, J. T., Greene, T., Agodoa, L. Y., Astor, B. C., Bakris, G. L., Cleveland, W. H., Charleston, J., Contreras, G. \& Faulkner, M. L. 2010. Intensive blood-pressure control in hypertensive chronic kidney disease. New England Journal of Medicine, 363, 918-929.

Babiker, F. A., Elkhalifa Lamia, A. \& Moukhyer, M. E. 2013. Awareness of hypertension and factors associated with uncontrolled hypertension in Sudanese adults. Cardiovascular journal of Africa, 24, 208.

Basu, S. \& Millett, C. 2013. Social epidemiology of hypertension in middle-income countries: determinants of prevalence, diagnosis, treatment, and control in the WHO SAGE study. Hypertension, 62: 18-26.

Brown, M. \& Bussell, J. 2010. Medication Adherence: WHO Cares? Mayo Clinical Proceedings, 86, 304-314.

Chow, C., Teo, K., Rangarajan, S., Islam, S., Gupta, R., Avezum, A., Bahonar, A., Chifamba, J., Dagenais, G. \& Diaz, R. 2013. PURE (Prospective Urban Rural Epidemiology) Study investigators. Prevalence, awareness, treatment, and control of hypertension in rural and urban communities in high-, middle-, and low-income countries. JAMA, 310, 959-68.

DASH, W. W. K. B. 2004. The DASH diet for high blood pressure: from clinical trial to dinner table. Cleveland Clinic journal of medicine, 71, 745 .

Kayima, J., Wanyenze, R. K., Katamba, A., Leontsini, E. \& Nuwaha, F. 2013. Hypertension awareness, treatment, and control in Africa: a systematic review. BMC cardiovascular disorders, 13, 54.

Lim, S. S., Vos, T., Flaxman, A. D., Danaei, G., Shibuya, K., Adair-Rohani, H., Almazroa, M. A., Amann, M., Anderson, H. R. \& Andrews, K. G. 2012. A comparative risk assessment of burden of disease and injury attributable to 67 risk factors and risk factor clusters in 21 regions, 1990-2010: a systematic analysis for the Global Burden of Disease Study 2010. The Lancet, 380, 2224-2260.

Mcevoy, L. K., Kritz-Silverstein, D., Barrett-Connor, E., Bergstrom, J. \& Laughlin, G. A. 2013. Changes in Alcohol Intake and Their Relationship with Health Status over a 24-Year Follow-Up Period in CommunityDwelling Older Adults. Journal of the American Geriatrics Society, 61, 1303-1308.

Mejía-Rodríguez, O., Paniagua-SIerra, R., Del Refugio Valencia-Ortiz, M., Ruiz-Garcia, J., Figueroa-Núñez, B. \& Roa-Sanchez, V. 2009. Factors associated with uncontrolled hypertension. Salud publica de Mexico, 51, 291-297.

Morisky, D. E., Green, L. W. \& Levine, D. M. 1986. Concurrent and predictive validity of a self-reported measure of medication adherence. Medical care, 67-74.

Musinguzi, G. \& Nuwaha, F. 2013. Prevalence, awareness, and control of hypertension in Uganda. PloS one, 8, e62236.

Musinguzi, G., Van Geertruyden, J. P., Bastiaens, H. \& Nuwaha, F. 2015. Uncontrolled Hypertension in Uganda: A Comparative Cross-Sectional Study. The Journal of Clinical Hypertension, 17, 63-69. 
Mutua, E. M., Gitonga, M. M., Mbuthia, B., Muiruri, N., Cheptum, J. J. \& Maingi, T. 2014. Level of blood pressure control among hypertensive patients on follow-up in a Regional Referral Hospital in Central Kenya. The Pan African Medical Journal, 18.

Pires, J. E., Sebastião, Y. V., Langa, A. J. \& Nery, S. V. 2013. Hypertension in Northern Angola: prevalence, associated factors, awareness, treatment, and control. BMC public health, 13, 90.

Sarfo, F. S., Mobula, L. M., Burnham, G., Ansong, D., Plange-Rhule, J., Sarfo-Kantanka, O. \& Ofori-Adjei, D. 2018. Factors associated with uncontrolled blood pressure among Ghanaians: Evidence from a multicenter hospital-based study. PloS one, 13, e0193494.

Sinkiewicz, W. \& Weglarz, M. 2009. Alcohol and wine and cardiovascular diseases in epidemiologic studies. Przeglad lekarski, 66, 233-238.

Tesfaye, B., Haile, D., Lake, B., Belachew, T., Tesfaye, T. \& Abera, H. 2017. Uncontrolled hypertension and associated factors among adult hypertensive patients on follow-up at Jimma University teaching and specialized hospital: a cross-sectional study. Research Reports in Clinical Cardiology, 8, 21-29.

Teshome, D. F., Demssie, A. F. \& Zeleke, B. M. 2018. Determinants of blood pressure control amongst hypertensive patients in Northwest Ethiopia. PloS one, 13, e0196535.

Wagner, A., Sadoun, A., Dallongeville, J., Ferrières, J., Amouyel, P., Ruidavets, J.-B. \& Arveiler, D. 2011. High blood pressure prevalence and control in a middle-aged French population and their associated factors: the MONA LISA study. Journal of hypertension, 29, 43-50.

WHO 2010a. Global Recommendations on Physical Activity for Health. WHO, Geneva.

WHO 2010b. Population-based prevention strategies for childhood obesity: report of a WHO forum and technical meeting, Geneva, 15-17 December 2009.

WHO 2013. A global brief on hypertension: silent killer, global public health crisis: World Health Day 2013 